\title{
Physiological and Nutritional Responses of Pear Seedlings to Nitrate Concentrations
}

\author{
Guodong Chen', Li Wang', Musana R. Fabricet, Yanan Tian, Kaijie Qi, Qian Chen, \\ Peng Cao, Peng Wang, Shaoling Zhang, Juyou Wu* and Shutian Tao*
}

Center of Pear Engineering Technology Research, State Key Laboratory of Crop Genetics and Germplasm Enhancement, College of Horticulture, Nanjing Agricultural University, Nanjing, China

OPEN ACCESS

Edited by:

Abraham J. Escobar-Gutiérrez, Institut National de la Recherche

Agronomique (INRA), France

Reviewed by:

Eddo Rugini,

Università degli Studi della Tuscia, Italy Maria Teresa Beryl Colinas León,

Chapingo Autonomous University,

Mexico

Katarzyna Glowacka

University of Nebraska-Lincoln,

United States

*Correspondence:

Juyou Wu

juyouwu@njau.edu.cn

Shutian Tao

taost@njau.edu.cn

†These authors have contributed equally to this work

Specialty section:

This article was submitted to

Crop and Product Physiology,

a section of the journal

Frontiers in Plant Science

Received: 24 February 2018

Accepted: 29 October 2018

Published: 20 November 2018

Citation:

Chen G, Wang L, Fabrice MR, Tian Y, Qi K, Chen Q, Cao P, Wang P,

Zhang S, Wu J and Tao S (2018)

Physiological and Nutritional

Responses of Pear Seedlings

to Nitrate Concentrations.

Front. Plant Sci. 9:1679.

doi: 10.3389/fp/s.2018.01679
Nitrogen $(\mathrm{N})$ is an important element for plant growth, and a suitable $\mathrm{N}$ supply is crucial to ensure optimal yields from fruit trees. Frequently, application of $\mathrm{N}$ fertilizers to fruit trees is often excessive, which not only leads to environmental pollution, but also reduces the output from fruit trees through $\mathrm{N}$ toxicity. To evaluate the effects of different concentrations of nitrate on plant growth, root-morphological traits, and other nutritional element's responses in pear, pear seedlings (Pyrus betulifolia Bunge) were treated with five levels of $\mathrm{N}$. Both $\mathrm{N}$-deficiency and an excess of $\mathrm{N}$ inhibited the growth and development of pear rootstocks. However, different visible symptoms were observed among treated leaves and roots. Leaf yellowing, the stimulation of root elongation, a decrease in nitrate reductase activity and chlorophyll content were observed under $\mathrm{N}$-deficiency conditions. On the other hand, dark green leaves accompanied by coking, the suppression of root elongation, and a decrease in nitrate reductase activity and chlorophyll content were displayed under regimes of excess N. In addition, not only the $\mathrm{N}$ content, but also the content of other mineral nutrients was influenced by nitrate treatments. Taken together, these results suggested that a careful choice of $\mathrm{N}$ fertilizer supply is crucial to ensure normal growth and development in pear trees.

Keywords: rootstock, root system architecture, physiological performance, nutrients, elements

\section{INTRODUCTION}

Nitrogen is one of the most abundant elements on Earth (Crawford and Glass, 1998; Hirsch and Sussman, 1999). However, the level of biologically available $\mathrm{N}$ often fails to meet crop requirements in agricultural systems having aerobic soils, in which nitrate is easily leached under high rainfall conditions (Fernández-Escobar et al., 2004; Giles, 2005; Masclaux-Daubresse et al., 2010; Canales et al., 2014). Thus, $\mathrm{N}$ is still one of the major factors limiting crop yields.

It is well known that $\mathrm{N}$ deficiencies limit plant growth and development, thereby reducing crop yields. The major causal effects of N-deficiency are reductions in protein synthesis and the chlorophyll content, resulting in a reduced accumulation of photosynthetic products (Daughtry et al., 2000; Hirel et al., 2011; Alvarez et al., 2012). On the other hand, the excessive use of $\mathrm{N}$ fertilizers not only requires a greater investment from farmer for a reduced crop yield, but also

Abbreviations: ABA, abscisic acid; IAA, auxin; ICP, inductively coupled plasma; LR, lateral root; N, Nitrogen; RSA, root system architecture; TTC, triphenyl tetrazolium chloride. 
leads to $\mathrm{N}$ contamination of the groundwater (Jaynes et al., 2001). Therefore, the establishment of a reasonable $\mathrm{N}$ supply to crops is fundamental to balance gains in crop yields against the increasing costs of $\mathrm{N}$ fertilizer and the need to minimize environmental perturbations, especially water quality.

Previous studies have shown that RSA plays a critical role in plant adaptation to external, environmental fluctuations. Plant roots can exhibit different physiological characteristics when grown under different $\mathrm{N}$ concentrations (Lynch, 1995; Osmont et al., 2007). In addition, $\mathrm{NO}_{3}^{-}$deficiency causes an increase in root hair length and density in spinach (Lynch, 1995; Gruber et al., 2013), and to a lesser extent in tomato (Foehse and Jungk, 1983). Furthermore, total root size, primary root length, and first- and second-order LR numbers significantly increased under conditions of nitrate starvation in wheat (Sinha et al., 2015). In contrast, excess $\mathrm{N}$ causes a decrease in primary root length and LR elongation in Arabidopsis (Zhang et al., 1999; Linkohr et al., 2002). Taken together, we may conclude that the availability of different concentrations of $\mathrm{N}$ can evoke distinct effects on the RSA.

In China, pear is the third most important fruit crop, and China leads the world in pear production and has the largest area of cultivation dedicated to this crop (Wu et al., 2013). The production of pear is significantly influenced by different levels of $\mathrm{N}$ supply. However, little is known about its adaptability to a deficient or excessive $\mathrm{N}$ level. Thus, the objectives of this study were to evaluate the effects of excessive and deficient $\mathrm{N}$ levels on growth, root-morphological traits, root activity, nitrate reductase activity, and the contents of $\mathrm{N}$ and other mineral nutritional elements, as well as to investigate the relationship among physiological performance, physiological activity, and mineral nutrients. These results highlight the necessity to determine the optimal supply of $\mathrm{N}$ fertilizer to optimize yields from pear and other fruit tree species.

\section{MATERIALS AND METHODS}

\section{Plant Materials and Treatment}

Birch-leaf pear (Pyrus betulifolia Bunge) were used in these experiments. First, seeds were soaked with water for $24 \mathrm{~h}$ and surface sterilized for $15 \mathrm{~min}$ in a $3 \%$ sodium hypochlorite solution and then rinsed repeatedly by deionized water. Seeds were mixed with sand (5-10\% moisture content) to a volume ratio of 1:4, placed in a mesh bag and placed at the bottom of a foam box with moist sand and then transferred to $4^{\circ} \mathrm{C}$ for stratification for 40 days. They were then transferred into a growth chamber for 2 days until seed germination, before being sown into $5 \times 10$ hole plastic containers filled with vermiculite. After 14 days, 45 seedlings of uniform size were selected, and then seedlings were solution-cultured in a plastic barrel covered with black KT board (Surin Flower Company, China) under growth chamber conditions. Seedlings were precultured in $1 / 2$ Hoagland's nutrient solution for 1 week until the growth of new roots, and then placed in $1 \times$ strength Hoagland's nutrient solution containing $\mathrm{NO}_{3}^{-}$at either 16 (control), 0, 4, 32, or $64 \mathrm{mM}$. Nine seedlings were used per treatment, with three replications. The seedlings were randomly arranged and cultured for 5 weeks, when typical symptoms of deficient or excess $\mathrm{N}$ became apparent.

The experiment was carried out in a growth chamber (Jiangnan Instrument, Ningbo, China) with a light/dark regime of $14 / 10 \mathrm{~h}$, at $28 / 22^{\circ} \mathrm{C}$, and $75 \%$ relative humidity, with a light intensity of $800 \mu \mathrm{mol} \mathrm{m} \mathrm{m}^{-2} \mathrm{~s}^{-1}$ of photosynthetically active radiation. Full strength Hoagland's nutrient solution was used as the base for deficient or excess $\mathrm{N}$ nutritive solutions, which contained $14 \mathrm{mM} \mathrm{NaNO}, 1 \mathrm{mM} \mathrm{Ca}\left(\mathrm{NO}_{3}\right)_{2} \cdot 4 \mathrm{H}_{2} \mathrm{O}, 1 \mathrm{mM}$ $\mathrm{KH}_{2} \mathrm{PO}_{4}, 2 \mathrm{mM} \mathrm{MgSO} \cdot 7 \mathrm{H}_{2} \mathrm{O}, 0.83 \mathrm{mg} \cdot \mathrm{L}^{-1} \mathrm{KI}, 6.2 \mathrm{mg} \cdot \mathrm{L}^{-1}$ $\mathrm{H}_{3} \mathrm{BO}_{3}, 22.3 \mathrm{mg} \cdot \mathrm{L}^{-1} \mathrm{MnSO}_{4}, 8.6 \mathrm{mg} \cdot \mathrm{L}^{-1} \mathrm{ZnSO}_{4}, 0.025 \mathrm{mg} \cdot \mathrm{L}^{-1}$ $\mathrm{CuSO}_{4}, 0.025 \mathrm{mg} \cdot \mathrm{L}^{-1} \mathrm{CoCl}_{2}, 0.25 \mathrm{mg} \cdot \mathrm{L}^{-1} \mathrm{Na}_{2} \mathrm{MoO}_{4}$, and $50 \mu \mathrm{M}$ Fe-EDTA (Hoagland and Arnon, 1950) (Table 1). The solution was ventilated for $30 \mathrm{~min}$ every $3 \mathrm{~h}$ by the combined action of a timer (Pinyi AL-06, China) and ventilation pump (SUNSUN ACO, China), and replaced twice a week. The $\mathrm{pH}$ of all nutrient solutions was adjusted to 5.8 with $0.1 \mathrm{M} \mathrm{KOH}$.

\section{Sampling and Plant Growth Parameter Measurements}

At the end of the experiment (after 5 weeks of treatment), plants of each treatment were harvested randomly, rinsed with deionized water, blotted carefully with tissue paper, and divided into leaf, stem, and root. Leaf area $\left(\mathrm{cm}^{2}\right)$ was measured by a leaf area meter (Li-3100C; LI-COR Biosciences Inc., Lincoln, NB, United States). The fresh weight of shoots and roots were measured by an electronic analytical balance (FA, 2014), and the fresh shoot weight/fresh root weight (S/R) ratio was calculated. Seedling height $(\mathrm{cm})$ and taproot length $(\mathrm{cm})$ were measured using a scaled ruler. The representative roots and leaves from the different $\mathrm{N}$ treatments were imaged using a PowerShot Pro 1 camera (Canon, Tokyo, Japan).

Root activity was measured by the TTC method (Baozhang et al., 1994). Briefly, $0.5 \mathrm{~g}$ of the root tip samples, after being rinsed with deionized water were placed into a breaker containing $10 \mathrm{~mL}$ mixture solution with the same volumes of $0.4 \%$ TTC and phosphate buffer solutions. Roots were fully immersed in the solution and incubated at $37^{\circ} \mathrm{C}$ for $3 \mathrm{~h}$ under dark conditions. Then $2 \mathrm{~mL}$ of $1 \mathrm{~mol} / \mathrm{L}$ sulfuric acid was added to stop the reaction. The roots were removed and blotted carefully with tissue paper. The formazan was extracted in $10 \mathrm{~mL}$ of ethyl acetate solution by grinding for $5 \mathrm{~min}$ with a mortar and pestle. Next, the homogenate was transferred into a $10 \mathrm{~mL}$ falcon tube and spun at $3,000 \times g$ for $10 \mathrm{~min}$. The supernatant was transferred into a new $10 \mathrm{~mL}$ falcon tube. The optical density (absorbance) of the extract was measured at $485 \mathrm{~nm}$ with a UV-1800 spectrophotometer (AuCy, China). The root activity was calculated by the following formula: Reduction strength of tetrazolium $[\mathrm{mg} / \mathrm{g}$ (root fresh weight $/ \mathrm{h}]=$ reduction amount of tetrazolium $(\mathrm{mg}) /[$ root weight (g) $\times$ time $(\mathrm{h})]$.

\section{Analysis of Root System Architecture (RSA)}

Seedlings of pear were randomly sampled in each treatment group and rinsed with deionized water before analysis. For the RSA analysis, root samples were scanned using an Epson digital 
TABLE 1 | Composition of the nutrient solution used for the experiment.

\begin{tabular}{|c|c|c|c|c|c|c|}
\hline Composition & & $0 \mathrm{mM}$ & $4 \mathrm{mM}$ & $16 \mathrm{mM}$ & $32 \mathrm{mM}$ & $64 \mathrm{mM}$ \\
\hline \multirow[t]{6}{*}{ Macroelement (mM) } & $\mathrm{KH}_{2} \mathrm{PO}_{4}$ & 1 & 1 & 1 & 1 & 1 \\
\hline & $\mathrm{MgSO}_{4} \cdot 7 \mathrm{H}_{2} \mathrm{O}$ & 2 & 2 & 2 & 2 & 2 \\
\hline & $\mathrm{KCl}$ & 5 & 5 & 5 & 5 & 5 \\
\hline & $\mathrm{Ca}\left(\mathrm{NO}_{3}\right)_{2} \cdot 4 \mathrm{H}_{2} \mathrm{O}$ & 0 & 0.5 & 1 & 1 & 1 \\
\hline & $\mathrm{CaCl}_{2}$ & 4 & 2 & 0 & 0 & 0 \\
\hline & $\mathrm{NaNO}_{3}$ & 0 & 0 & 14 & 30 & 62 \\
\hline \multirow[t]{7}{*}{ Microelement (mg/L) } & $\mathrm{KI}$ & 0.83 & 0.83 & 0.83 & 0.83 & 0.83 \\
\hline & $\mathrm{H}_{3} \mathrm{BO}_{3}$ & 6.2 & 6.2 & 6.2 & 6.2 & 6.2 \\
\hline & $\mathrm{ZnSO}_{4}$ & 8.6 & 8.6 & 8.6 & 8.6 & 8.6 \\
\hline & $\mathrm{Na}_{2} \mathrm{MoO}_{4}$ & 0.25 & 0.25 & 0.25 & 0.25 & 0.25 \\
\hline & $\mathrm{CuSO}_{4}$ & 0.025 & 0.025 & 0.025 & 0.025 & 0.025 \\
\hline & $\mathrm{CoCl}_{2}$ & 0.025 & 0.025 & 0.025 & 0.025 & 0.025 \\
\hline & $\mathrm{MnSO}_{4}$ & 22.3 & 22.3 & 22.3 & 22.3 & 22.3 \\
\hline Iron salt (mM) & EDTA-Fe & 0.05 & 0.05 & 0.05 & 0.05 & 0.05 \\
\hline
\end{tabular}

scanner (Expression 10000XL 1.0, Epson Inc., Japan), and the root images were analyzed with WinRhizo software (Regent Instruments Canada Inc., 2013). Traits of total root length, total root surface area, total root volume, total root number per plant and average root diameter were calculated for each nitrate treatment.

\section{Chlorophyll Measurement}

Chlorophyll was extracted from samples of $100 \mathrm{mg}$ fresh leaves which were cut into small pieces with scissors and ground for $5 \mathrm{~min}$ in $10 \mathrm{~mL}$ of $85 \%$ acetone with a mortar and pestle. The homogenate was sieved through filter paper, transferred into a $15 \mathrm{~mL}$ Falcon tube, and adjusted to a set volume with $85 \%$ acetone. The absorbance of the extract was measured at both 663 and $644 \mathrm{~nm}$ with a UV-1800 spectrophotometer (AuCy, China). The concentrations of chlorophyll a and b, in mg per gram of FW sample, were calculated using the following formulae:

$$
\begin{aligned}
& \text { Milligrams chlorophyll a/g FW }=1.07\left(\mathrm{OD}_{663}\right) \\
& -0.094\left(\mathrm{OD}_{644}\right) \\
& \text { Milligrams chlorophyll b/g FW }=1.77\left(\mathrm{OD}_{644}\right) \\
& -0.280\left(\mathrm{OD}_{663}\right)
\end{aligned}
$$$$
\text { Total chlorophyll }=\text { chlorophyll } \mathrm{a}+\text { chlorophyll } \mathrm{b}
$$

\section{Nitrate Reductase Activity Measurement}

For determination of nitrate reductase activity, leaves or roots harvested after the different $\mathrm{N}$ treatments were rinsed with distilled water, air-dried, and immersed in $10 \mathrm{~mL}$ of extraction buffer containing $1 \mathrm{~mL} \mathrm{30 \%} \mathrm{trichloroacetic} \mathrm{acid,} 4 \mathrm{~mL}$ $0.1 \mathrm{~mol} \cdot \mathrm{L}^{-1}$ phosphate buffer $(\mathrm{pH} 7.5)$ and $5 \mathrm{~mL} 0.2 \mathrm{~mol} \cdot \mathrm{L}^{-1}$ $\mathrm{KNO}_{3}$ for $30 \mathrm{~min}$ at $30^{\circ} \mathrm{C}$ in the dark. After $30 \mathrm{~min}, 1 \mathrm{~mL} 30 \%$ trichloroacetic acid was the added and the solution was agitated. The reaction was stopped by centrifugation at $6,000 \times g$ for $8 \mathrm{~min}$. $2 \mathrm{~mL}$ of the supernatant was treated with $4 \mathrm{~mL} 1 \%$ sulfonamide and $0.2 \% \alpha$-naphthylamine before incubating for $20 \mathrm{~min}$ at $30^{\circ} \mathrm{C}$ in a water bath with agitation. Nitrate reductase activity was then measured at $540 \mathrm{~nm}$ using a UV-1800 spectrophotometer (AuCy, China). The level of nitrate reductase activity, the amount of nitrite produced in nmol per FW (g) root or foliage tissue per hour, was calculated by the following formula: NR activity $(\mu \mathrm{g} / \mathrm{g}$ $\mathrm{FW} \cdot \mathrm{h})=$ Nitrite content $(\mu \mathrm{g}) \times$ sample dilution multiple/sample FW $(\mathrm{g}) \times$ time $(\mathrm{h})$.

\section{Elemental Analysis}

The dried roots, shoots, and leaves (100-900 mg) were weighed into PTFE digestion tubes and digested by nitric acid with a microwave digester (Ultraclave 4; MLS). Elemental content analysis was undertaken by ICP optical emission spectroscopy (ICP 6500 dual OES spectrometer; Thermo Fischer Scientific, Waltham, MA, United States). For $\mathrm{N}$ analysis, the dried plants were frozen and ground in a ball mill. One $\mathrm{mg}$ of the ground material was taken for analysis using a Kjeldahl apparatus (JK9870).

\section{Experimental Design and Statistical Analyses}

The experiment was established in a completely randomized $1 \times 5$ factorial design with one rootstock source subject to five $\mathrm{N}$ treatments $(0,4,16,32$, and $64 \mathrm{mM} \mathrm{N})$. Three replicates (three plants per replicate) were used for each treatment. Statistical analyses of the data were performed using the SPSS statistical package and the differences were statistically compared by employing the Duncan test with a significance level of $p<0.05$.

\section{RESULTS}

\section{Visible Symptoms and Plant Growth}

Significant variations were observed with different $\mathrm{N}$ treatments in our experiment. As shown in Figure 1, N deficiency and excess $\mathrm{N}$ treatments significantly influenced the growth and development of the pear seedlings. Seedlings displayed the best growth and development in the presence of $16 \mathrm{mM} \mathrm{N}$, whereas extension of the stem and leaf expansion were significantly 
inhibited under $\mathrm{N}$ deficiency conditions $(p<0.05)$ (Figures 1A, $2 \mathrm{~B}, \mathrm{C})$. Conversely, $\mathrm{N}$ deficiency stimulated the elongation of the root (Figure 1C). On the other hand, the growth of both the shoot and root were inhibited with excess $\mathrm{N}$, especially in the root (Figure 1C). Since N can be transferred from old leaves to young leaves, $\mathrm{N}$ deficiency symptoms first appear in the older leaves, most of which discolor to light green-yellow and undergo early defoliation under severe $\mathrm{N}$-deficiency conditions (Figure 1B), which are the typical symptoms of $\mathrm{N}$ deficiency in plants. Furthermore, the symptoms of the $\mathrm{N}$ deficiency in the leaf were reduced under conditions of moderate $\mathrm{N}$ deficiency $(4 \mathrm{mM})$, where lighter yellow and larger leaves were exhibited relative to the severe N-deficient supply (Figure 1B). On the other hand, an excess supply of $\mathrm{N}$ induced symptoms different from those of $\mathrm{N}$ deficiency, i.e., a dark green leaf color accompanied by a scorch phenomenon, and these symptoms became more pronounced when the supply of $\mathrm{N}$ was increased (Figure 1B). In summary, $\mathrm{N}$ deficiency and excess $\mathrm{N}$ supply leads to the inhibition of pear seedling growth and development.

\section{Root Architectural Plasticity in Responses to $\mathbf{N}$ Treatments}

In order to evaluate the effect of different levels $\mathrm{N}$ supply on the growth and development of the pear, the agronomic traits such as RSA, plant height, leaf number, leaf area, and physiological and biochemical traits such as mineral nutrient content, chlorophyll content, root activity, and nitrate reductase activity were further analyzed.

Consistent with the above studies, N-deficiency stimulated the growth of a more exploratory root system, which was longer and more highly branched (Forde and Lorenzo, 2001; Little et al., 2005; Luo et al., 2013). Detailed RSA analyses revealed that a low $\mathrm{N}$ supply not only stimulated LR length, but also increased the number of LR per plant relative to the control $\mathrm{N}$ treatment $(16 \mathrm{mM})$, thereby significantly increasing the total plant root length, root surface area, and root volume (Table 2). Moreover, this stimulatory effect was markedly increased when further reducing the $\mathrm{N}$ supply from a moderate $\mathrm{N}$ deficiency $(4 \mathrm{mM})$ to a severe $\mathrm{N}$ deficiency $(0 \mathrm{mM}$; Table 2$)$. However, the average root diameter showed no significant changes among these $\mathrm{N}$ treatments. On the other hand, the maximum root length, total root length, total root number, and total root surface area per plant showed a significant reduction in response to an excess supply of N. However, no significant difference was observed in the total root volume per plant between conditions of moderate and severe excesses of $\mathrm{N}$ treatments (Table 2).

\section{The Effect of $\mathbf{N}$ Treatments on the Aerial Growth of Pear Seedlings}

The shoots of pear seedlings are also highly sensitive to different $\mathrm{N}$ treatments. Both 4-mM N and 0-mM N-treated plants had significantly shorter heights and reduced leaf numbers and leaf areas, relative to control conditions $(16 \mathrm{mM} \mathrm{N})$. For the 4$\mathrm{mM}$ N-treated plants, the leaf number, leaf area, and plant height decreased by 8\% (Figure 2A), 18\% (Figure 2B), and 18\% (Figure 2C), respectively, while in the $0-\mathrm{mM} \mathrm{N}$-treated plants,

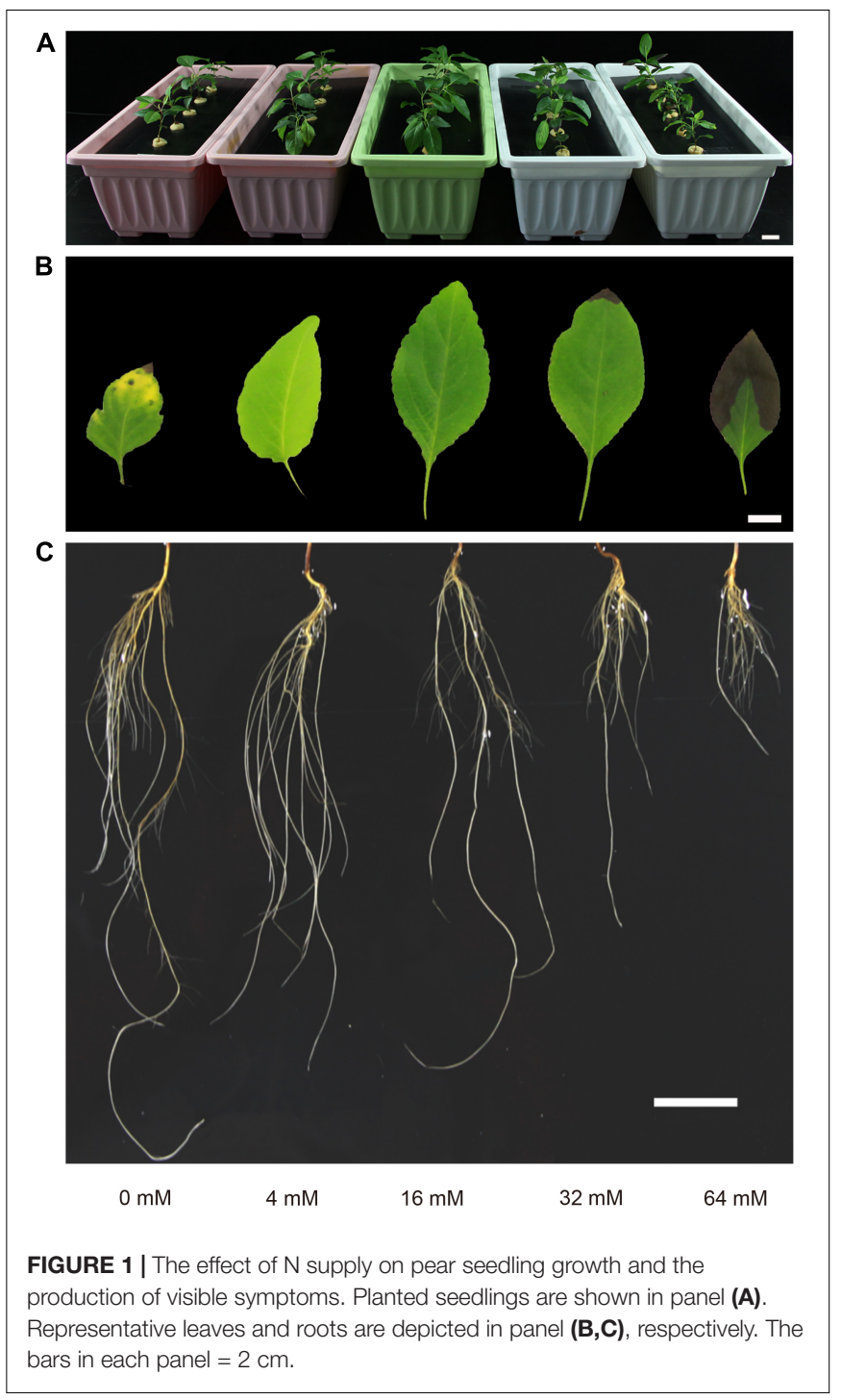

they decreased by 41\% (Figure 2A), 62\% (Figure 2B), and 38\% (Figure 2C), respectively.

\section{The Effect of $\mathbf{N}$ Treatments on the Ratio of Root/Shoot Fresh Weight}

To evaluate the effects of the $\mathrm{N}$ deficiency and $\mathrm{N}$ excess on the growth and development of the pear seedlings, the fresh weights of roots, stems, and leaves grown under different $\mathrm{N}$ treatments were determined and the ratio of root/shoot weight was calculated. Since the length and number of roots increased from 64 to $0 \mathrm{mM} \mathrm{N}$, the root fresh weight concomitantly increased. Compared to the $16 \mathrm{mM} \mathrm{N}$ control conditions, the $4 \mathrm{mM} \mathrm{N}$ and $0 \mathrm{mM} \mathrm{N}$ treatments resulted in a 16 and $43 \%$ root fresh weight increase, respectively (Figure 3A). On the other hand, because the growth of the stem and leaf were significantly suppressed under conditions of both $\mathrm{N}$ deficiency and $\mathrm{N}$ excess, the stem and leaf fresh weights initially increased with $\mathrm{N}$ supply from 0 to $16 \mathrm{mM}$, and then decreased at higher 
TABLE 2 | Effects of different $\mathrm{N}$ levels on root morphologic parameters of pear seedlings.

\begin{tabular}{|c|c|c|c|c|c|c|}
\hline $\begin{array}{l}\text { Treatments } \\
\text { per plant } \\
(\mathrm{mM})\end{array}$ & $\begin{array}{c}\text { Root } \\
\text { length } \\
\text { (cm) }\end{array}$ & $\begin{array}{c}\text { The max } \\
\text { length of root } \\
\text { (cm) }\end{array}$ & $\begin{array}{c}\text { Root } \\
\text { surface area } \\
\left(\mathrm{cm}^{2}\right)\end{array}$ & $\begin{array}{c}\text { Root } \\
\text { volume } \\
\left(\mathrm{cm}^{3}\right)\end{array}$ & $\begin{array}{c}\text { Root } \\
\text { number }\end{array}$ & $\begin{array}{c}\text { Diameter } \\
(\mathrm{mm})\end{array}$ \\
\hline 0 & $188.54^{a}$ & $25^{a}$ & $22.39^{a}$ & $0.17^{a}$ & $294^{a}$ & $0.3538^{a}$ \\
\hline 4 & $166.42^{b}$ & $20.5^{b}$ & $17.14^{b}$ & $0.14^{\mathrm{b}}$ & $158^{c}$ & $0.3501^{a}$ \\
\hline 16 & $144.15^{\mathrm{c}}$ & $16.67^{c}$ & $16.79^{b}$ & $0.1^{c}$ & $202^{b}$ & $0.3504^{a}$ \\
\hline 32 & $80.62^{d}$ & $12.67^{d}$ & $13.31^{c}$ & $0.07^{d}$ & $144^{c}$ & $0.3665^{a}$ \\
\hline 64 & $43.5^{\mathrm{e}}$ & $7^{e}$ & $7.77^{d}$ & $0.06^{d}$ & $94^{d}$ & $0.4016^{a}$ \\
\hline
\end{tabular}

All pear seedlings were grown under hydroponic conditions with the nitrogen supplies indicated for 5 weeks. Data are presented as the mean \pm SD of three replicates, and each replicate datum was derived from measurements from three plants.

Letters in superscript indicate whether mean values are significantly different between treatments ( $p<0.05$; different letters) or not (same letter).

A

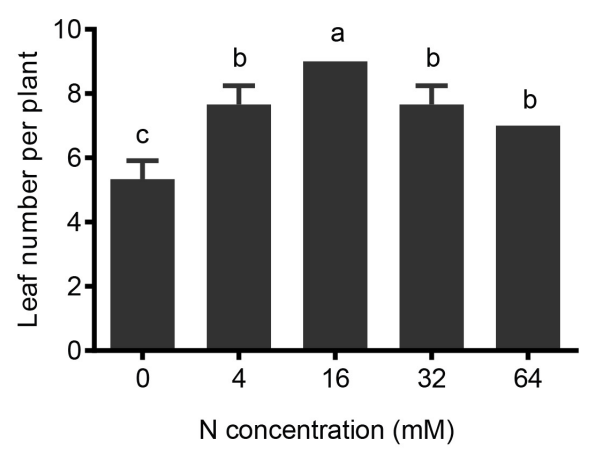

C

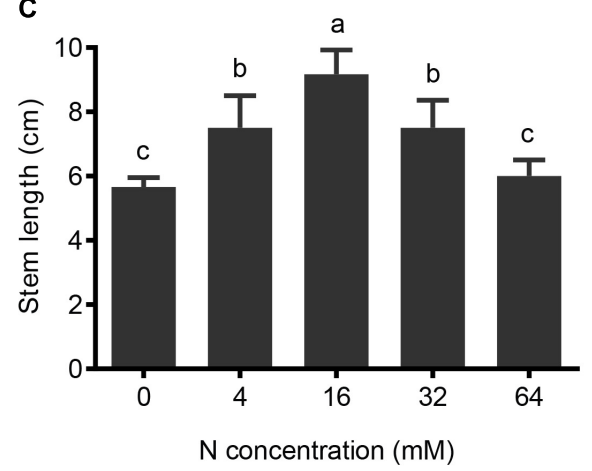

B

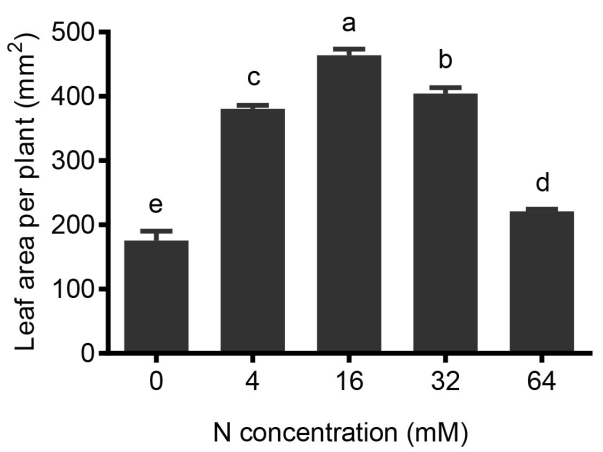

$\mathrm{N}$ concentration (mM)

FIGURE 2 | The effects of $\mathrm{N}$ treatments on pear shoot growth. (A) The leaf number per plant, (B) the leaf area per plant, and (C) the stem lengths were analyzed after different $\mathrm{N}$ treatments for 5 weeks. The data are presented as the means \pm SDs of three replicates, and each replicate is based on measurements made from three plants. Letters in superscript indicate whether significant differences ( $p<0.05)$ exist between different $\mathrm{N}$ treatments (differing letter) or not (same letter).

concentrations of supplied N (Figures 3B,C). Interestingly, leaf fresh weight appears to be more sensitive to changes in $\mathrm{N}$ conditions and demonstrates a significant difference between moderate $\mathrm{N}$ deficiency and a moderate excess of $\mathrm{N}$ supply, whereas no significant difference was found in stems under these conditions, suggesting leaves are more sensitive to changes in the $\mathrm{N}$ supply than stems. The ratio of root/shoot fresh weight mainly reflects the situation of the photosynthetic product distribution between the shoot and root (Figure 3D). The experimental results showed that roots displayed better growth than aerial portions of the plant under conditions of $\mathrm{N}$ deficiency, leading to a decrease in the root to shoot ratio when increasing the $\mathrm{N}$ supply from severe $\mathrm{N}$ deficiency to control (16 mM) conditions. However, no significant changes in the ratio could be detected between the control and higher (excess) levels of control supply, and this was mainly due to the fact that the growth of the shoot and root were both inhibited when further increasing the $\mathrm{N}$ supply.

\section{The Effect of $\mathbf{N}$ Treatments on Chlorophyll Concentrations}

As shown in Figure1B, yellowing and dark green of the leaves were observed in pear seedlings under $\mathrm{N}$ deficiency and $\mathrm{N}$ excess conditions, respectively. In order to investigate the impact of 

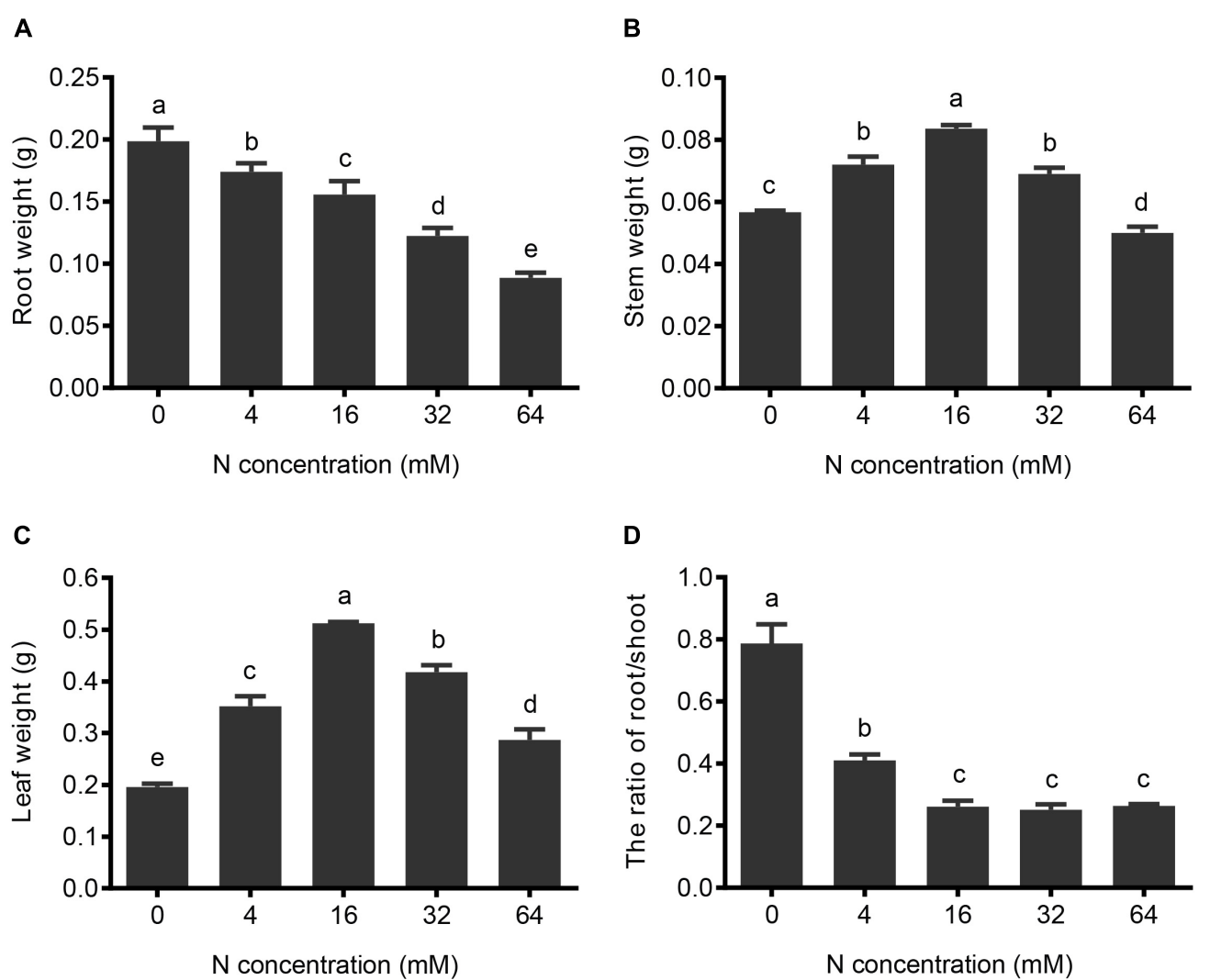

FIGURE 3 | The effects of $\mathrm{N}$ treatments on the fresh weight of the different parts of the pear. (A) Root fresh weight, (B) stem fresh weight, and (C) leaf fresh weight under different $\mathrm{N}$ concentrations were determined. (D) Root fresh weight/shoot fresh weight ratio was calculated according to the results shown in (A-C). The data are presented as described in Figure 2.

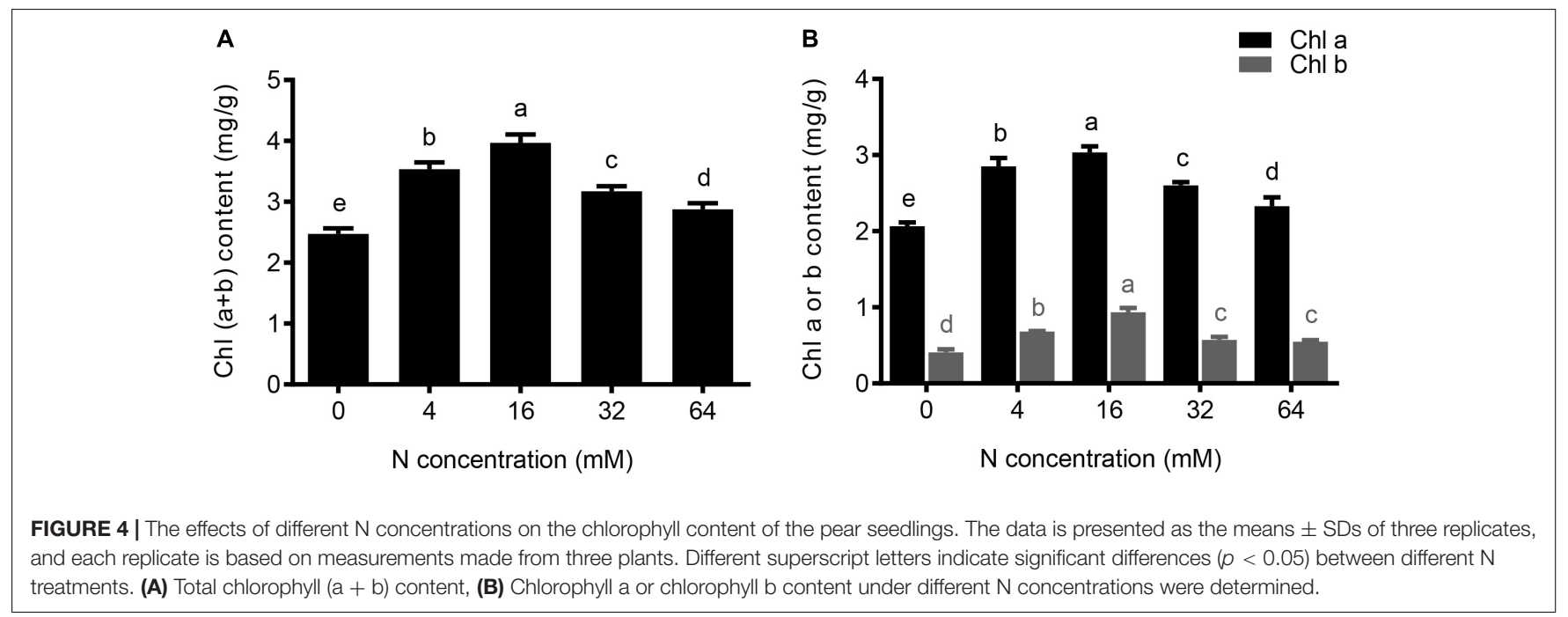

$\mathrm{N}$ treatments on leaf chlorophyll, the leaf chlorophyll contents among five $\mathrm{N}$ treatment plants were examined. Comparisons of the data in Figure 4A showed that the total leaf chlorophyll content significantly decreased by 11 and $38 \%$ in $4-$ and $0-\mathrm{mM}$ $\mathrm{N}$-treated plants, respectively, compared with control $(16 \mathrm{mM})$ plants. In addition, the synthesis of the total chlorophyll was also significantly inhibited with a moderate and severe excess in $\mathrm{N}$ supply, decreasing by 20 and $27 \%$ in the presence of the 32 and $64 \mathrm{mM} \mathrm{N}$, respectively, compared to control plants (Figure 4A). Furthermore, the trends of chlorophyll a and chlorophyll b levels in response to the increasing $\mathrm{NO}_{3}^{-}$concentrations, were similar to that of total chlorophyll (Figure 4B). Taken together these 
results indicated that the inhibition effect induced by an excessive supply of $\mathrm{N}$ is between those observed under conditions of severe $\mathrm{N}$ deficiency and moderate $\mathrm{N}$ deficiency.

\section{The Effect of $\mathbf{N}$ Treatments on Root Activity}

To some extent, a strong root system activity is indicative of a vigorous root metabolism and absorption capacity. As shown in Figure 5, the root activity was markedly decreased in response to both $\mathrm{N}$-deficient and $\mathrm{N}$-excess treatments, whereas, relative to the control ( $16 \mathrm{mM} \mathrm{N}$ ), it was decreased by 48 and $51 \%$ at 4 and $0 \mathrm{mM} \mathrm{N}$, and by 45 and $70 \%$, in $32 \mathrm{mM}$ and $64 \mathrm{~N}$-treated plants, respectively. Taken together these results suggested that the root activity was severely inhibited by $\mathrm{N}$ deficiency and an excess supply of $\mathrm{N}$.

\section{Effects of Different Nitrate Levels on Nitrate Reductase Activity in Pear Seedlings}

Nitrate reductase is one of the key enzymes in plant $\mathrm{N}$ metabolism and assimilation process. Its activity determines the rate of assimilating nitrate into organic $N$. Nitrate reductase is an inducible enzyme whose abundance is affected by the exterior concentration of nitrate. Therefore, we investigated the effects of different concentrations of exogenous nitrate ions on the nitrate reductase activity in leaves and roots of pear seedlings.

As shown in Figure 6A, N deficiency and $\mathrm{N}$ excess treatments significantly reduced the nitrate reductase activity in pear root; moreover, the inhibitory effect under conditions of $\mathrm{N}$ deficiency is greater than that under conditions of excess N. However, no significant difference was detected between conditions of severe and moderate $\mathrm{N}$ deficiency or between severe and moderate excess of $\mathrm{N}$. The nitrate reductase activity in leaves is also clearly influenced by the different $\mathrm{N}$ treatments (Figure 6B). The results show that significant differences were observed among these five $\mathrm{N}$ treatments, the nitrate reductase activity in leaf decreased compared with root under both of deficient and excessive $\mathrm{N}$ conditions.

\section{Mineral Element Contents in Different Seedling Organs}

The concentrations of mineral macronutrients $(\mathrm{N}, \mathrm{P}, \mathrm{K}, \mathrm{Ca}$, and $\mathrm{Mg}$ ) and micronutrients $(\mathrm{Fe}, \mathrm{Mn}, \mathrm{B}, \mathrm{Zn}$, and $\mathrm{Cu}$ ) in roots, stems, and leaves of pear seedlings treated with five levels of $\mathrm{N}$ are presented in Figure 7. The endogenous $\mathrm{N}$ concentration in the roots gradually increased with increasing $\mathrm{N}$ supply when the level of $\mathrm{N}$ supply was less than $16 \mathrm{mM}$, but significantly decreased when the $\mathrm{N}$ supply was over $16 \mathrm{mM}$ (Figure 7A, left panel). It is worth noting that in pear root, compared with the $\mathrm{N}$ content, the $\mathrm{P}$ and $\mathrm{K}$ contents showed different trends when the plants were grown in an $\mathrm{N}$-deficient ( 0 or $4 \mathrm{mM}$ ) environment. They showed a significant decrease when the $\mathrm{N}$ supply increased from 0 to $4 \mathrm{mM}$. However, the $\mathrm{P}$ and $\mathrm{K}$ contents showed similar trends to that of the $\mathrm{N}$ when the $\mathrm{N}$ supply increased from 4 to $64 \mathrm{mM}$. $\mathrm{Ca}^{2+}$ and $\mathrm{Mg}^{2+}$ levels showed no significant differences under the $\mathrm{N}$ concentration increased from

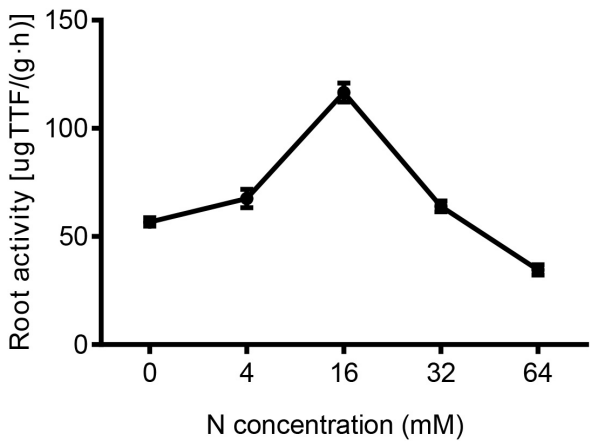

FIGURE 5 | The effects of different $\mathrm{N}$ concentrations on the root activity of the pear seedlings treated for 5 weeks. The data is presented as the means \pm SDs of three replicates $(n=3)$, and each replicate is based on measurements made from three plants.

4 to $32 \mathrm{mM}$, while a severe excess $\mathrm{N}$ supply markedly reduced the concentrations of $\mathrm{Ca}^{2+}$ and $\mathrm{Mg}^{2+}$. It is interesting that the $\mathrm{Mg}$ concentration was markedly decreased when increasing the $\mathrm{N}$ supply from 0 to $4 \mathrm{mM}$. As shown in Figure 7A (right panel) not only the macronutrient concentrations, but also the micronutrients concentrations were influenced by different $\mathrm{N}$ treatments. The concentration of Fe displayed a similar trend to $\mathrm{P}$ and $\mathrm{K}$, which is markedly increased in the presence of $0 \mathrm{mM}$ N, but showed a significant decrease under severe $\mathrm{N}$-excess conditions. In addition, the concentration of $\mathrm{Mn}$ displayed a different trend to $\mathrm{Fe}$, showing a significant decrease under both $\mathrm{N}$ deficiency and excess treatments. Interestingly, $\mathrm{B}$ and $\mathrm{Cu}$ were hardly detected in the root.

Different trends were observed for both the macronutrients and micronutrients in the stem with different $\mathrm{N}$ treatments when compared to those displayed in the root (Figure 7B). It is worth noting that the maximal concentrations of all macronutrients, except for $\mathrm{Ca}$, were obtained at $4 \mathrm{mM} \mathrm{N}$, but not at $16 \mathrm{mM} \mathrm{N}$. As for the micronutrients, the contents of Fe, Mn, and $\mathrm{Zn}$ showed a similar trend in response to different $\mathrm{N}$ treatments, which was of a significant increase when increasing the $\mathrm{N}$ supply from 0 to $4 \mathrm{mM}$, but $\mathrm{B}$ and $\mathrm{Cu}$ showed no significant changes. Moreover, the concentrations of $\mathrm{Fe}$ and $\mathrm{B}$ displayed a significant increase when further increasing the $\mathrm{N}$ supply from 4 to $16 \mathrm{mM}$, but no significant changes were observed in $\mathrm{Mn}$ and $\mathrm{Zn}$. In addition, the concentrations of most micronutrients displayed an obvious decrease when further increasing the $\mathrm{N}$ supply to $32 \mathrm{mM}$, whereas no effects was observed on the concentrations of $\mathrm{Mn}$ and $\mathrm{Zn}$. Importantly, all micronutrients were significantly reduced in the presence of $32 \mathrm{mM} \mathrm{N}$ and most displayed no significant changes at the higher concentration of $64 \mathrm{mM}$ N. Conversely, Fe and Mn showed marked increases in response to this increase in $\mathrm{N}$.

The concentrations of the macronutrients and micronutrients in the leaf were also sensitive to different $\mathrm{N}$ treatments, as shown in Figure 7C, the concentrations of $\mathrm{N}$ were largely increased with increasing the $\mathrm{N}$ supply from 0 to $16 \mathrm{mM}$, but $\mathrm{P}, \mathrm{K}, \mathrm{Ca}$ and $\mathrm{Mg}$ were significantly increased when increasing the $\mathrm{N}$ supply from 0 to $4 \mathrm{mM}$, but not influenced by further increasing the $\mathrm{N}$ 

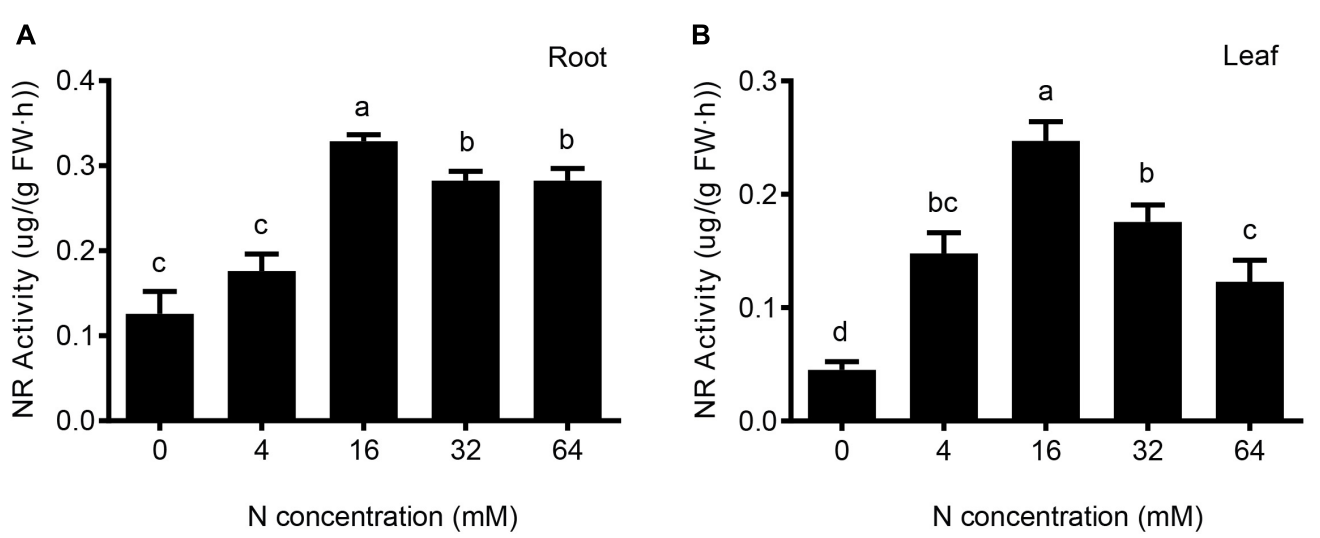

FIGURE 6 | The effects of different $\mathrm{N}$ levels on the nitrate reductase activity of the root $\mathbf{( A )}$ and leaf (B) were analyzed. The level of nitrate reductase activity was represented by the amount of nitrite produced in nmol per FW $(\mathrm{g})$ of root or foliage tissue per $\mathrm{h}$. The data are presented as the means \pm SDs of three replicates, and each replicate is based on measurements made from three plants. Different superscript letters indicate significant differences ( $p<0.05)$ exist between different $\mathrm{N}$ treatments.

supply to $16 \mathrm{mM}$. In the case of excess $\mathrm{N}$, the concentrations of $\mathrm{P}$ and $\mathrm{N}$ were significantly decreased, but the concentrations of $\mathrm{K}$, $\mathrm{Ca}$, and $\mathrm{Mg}$ displayed first a reduction and then an increase. Fe showed a similar trend to $\mathrm{N}$, while Mn exhibited a similar trend to $\mathrm{K}$. However, the concentrations of leaf $\mathrm{Zn}$ and $\mathrm{Cu}$ were not influenced by the $\mathrm{N}$ treatments. Furthermore, the concentration of B was markedly decreased with an excess supply of $\mathrm{N}$, but not affected by $\mathrm{N}$-deficiency.

\section{DISCUSSION}

\section{Symptoms and Plant Growth}

Several studies have shown that changes in $\mathrm{N}$ supply can induce physiological phenotypic changes in the plants (Gruber et al., 2013; Canales et al., 2014). In poplars, $\mathrm{N}$ deficiency induced root biomass production and inhibited the growth of shoots and leaves, whereas a high $\mathrm{N}$ supply repressed root growth and reduced shoot biomass (Luo et al., 2013; Euring et al., 2014). Studies in wheat also demonstrated that the root length was increased while the shoot length was reduced under $\mathrm{N}$-starvation conditions (Sinha et al., 2015). Consistent with previous results, the $\mathrm{N}$ deficiency caused the yellowing of mature leaves, and total root number and the fresh root weight were significantly increased under $\mathrm{N}$-deficiency conditions, but stem biomass, leaf number, leaf area and leaf biomass were markedly decreased. However, the excessive $\mathrm{N}$ treatment caused dark green leaves accompanied by coking, and root elongation, shoot extension and leaf expansion were all suppressed by the excessive $\mathrm{N}$ application. Thus, these results indicated that a moderate $\mathrm{N}$ fertilizer supply is crucial to ensure normal growth and development in pear trees.

\section{Relationship Between Physiological Performance and Mineral Nutrient Contents}

Previous research showed that mineral content can provide information regarding the functional state of organisms under different growth conditions (Thornton, 2002). Ionomics has been widely used in many plant mineral nutrient studies, such as in tomato (Sanchez-Rodriguez et al., 2010), rice (Norton et al., 2010), soybean (Wang et al., 2012), and grapevine (Sofo et al., 2013). Here, the mineral nutrient concentrations in the leaf, stem and root of the pear rootstocks exposed to different concentrations of $\mathrm{N}$ were analyzed to explain the symptoms of the pear under $\mathrm{N}$-stress conditions. Our results showed that not only endogenous $\mathrm{N}$ concentrations but also other mineral nutrient concentrations in the roots, stems and leaves of pear seedlings were influenced by $\mathrm{N}$-deficiency and $\mathrm{N}$-excess treatments. It may be that $\mathrm{N}$ has not only synergistic effects on other mineral elements, but also forms antagonistic effects, affecting other mineral elements' absorption, distribution or utilization in plants, and finally determining other mineral elements' contents in different plant organs (Feil and Banziger, 1993). It may also be that root activity is markedly decreased by $\mathrm{N}$-deficiency and $\mathrm{N}$-excess treatments, which then affects other mineral elements' absorption. For example, as shown in Figure 7C, the $\mathrm{N}$ content in the leaves significantly decreased under $\mathrm{N}$-deficiency conditions, whereas $\mathrm{Mg}$ levels appeared insignificantly changed when reducing the $\mathrm{N}$ supply from normal to moderate $\mathrm{N}$-deficiency. However, leaf $\mathrm{Mg}$ content was significantly decreased under severe $\mathrm{N}$-deficiency conditions. Because $\mathrm{N}$ is an important component of chlorophyll, and $\mathrm{Mg}$ occupies a central position in the chlorophyll molecule and enzymatic cofactor (Maathuis, 2009). We concluded that leaf yellowing under moderate $\mathrm{N}$-deficiency conditions could be attributed to the decrease in $\mathrm{N}$ concentration, while severe leaf yellowing in the presence of $0 \mathrm{mM} \mathrm{N}$ might be attributed to a decrease in the concentrations of $\mathrm{N}$ and $\mathrm{Mg}$. Additionally, $\mathrm{Fe}$ and $\mathrm{Mn}$ are essential elements for leaf chlorophyll metabolism and photosynthesis (Hansch and Mendel, 2009). Here, the leaf Fe and Mn contents were significant decreased under $\mathrm{N}$-deficiency conditions (Figure 7C). Thus, leaf yellowing in pear under $\mathrm{N}$-deficiency 

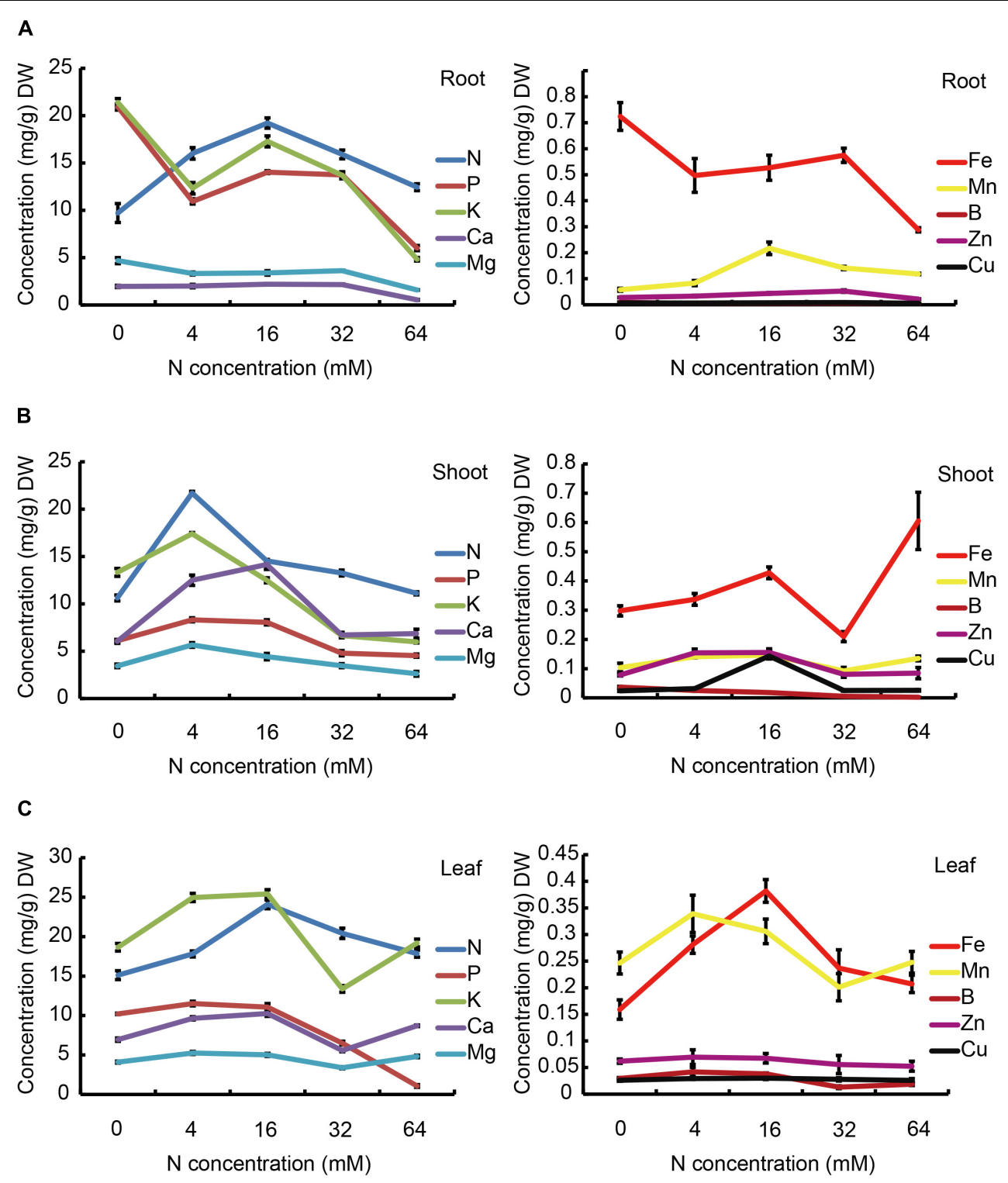

FIGURE 7 | The effects of $\mathrm{N}$ treatments on the macroelement and microelement contents of the root (A), stem (B), and leaf (C). The data are presented as the means \pm SDs of three replicates $(n=3)$, and each replicate is based on measurements made from three plants.

conditions may be caused by decreased concentrations of $\mathrm{N}$, $\mathrm{Mg}, \mathrm{Fe}$, and $\mathrm{Mn}$, which might affect the photosynthetic rate of pear.

In addition, the ionomic analysis indicated that a high $\mathrm{N}$ supply significantly reduced the contents of $\mathrm{P}, \mathrm{K}, \mathrm{Mg}, \mathrm{Fe}$ and $\mathrm{Mn}$ ions in the leaf, but the contents of $\mathrm{K}, \mathrm{Mg}$, and $\mathrm{Mn}$ under 64-mM N conditions were greater than those at $32 \mathrm{mM} \mathrm{N}$. It may be that the growth of the leaves was severely suppressed, leading to a concentration-dependent $\mathrm{N}$ effect. However, the $\mathrm{P}$ and $\mathrm{Mn}$ concentrations in the leaf significantly decreased as the $\mathrm{N}$ supply increased from 16 to $64 \mathrm{mM}$. The decrease in $\mathrm{P}$ concentration in particular leads to the typical symptoms of $\mathrm{P}$ deficiency, as indicated by the dark green leaves. Moreover, a shortage of $\mathrm{K}$ results in the leaf edges coking. Thus, an excessive
$\mathrm{N}$ supply appears to induces a shortage of $\mathrm{P}$ and $\mathrm{K}$ in pear leaves, contributing to the dark green color and coking.

\section{Possible Mechanisms That Underlie the Morphological and Physiological Phenotypes}

Higher root activity values indicate stronger root metabolic activities and absorption capacities (Haluskova et al., 2009). Our results showed that root activity was both inhibited under low and excessive $\mathrm{N}$ supply, but the inhibitory effect was more obvious under excess $\mathrm{N}$ than under $\mathrm{N}$-deficiency conditions. Based on the results mentioned above, we may conclude that $\mathrm{N}$ deficiency and $\mathrm{N}$ excess not only influenced the elongation of the pear 
root, but also suppressed root activity in pear. Additionally, nitrate reductase, a key enzyme in plant $\mathrm{N}$ assimilation and metabolism (Hirel et al., 2001), is also significantly reduced under $\mathrm{N}$-deficiency and $\mathrm{N}$-excess conditions. Thus, physiological phenotype correlated with changes in the biochemical indexes.

The molecular mechanism that underlies morphological and physiological acclimation under $\mathrm{N}$ starvation and excess has also been widely studied. It was reported that nitric oxide (NO) was considered a key regulator for root growth under conditions of $\mathrm{N}$-deficiency, where NO, together with strigolactones, may be involved in regulating IAA transport from the shoot to the root, leading to increases in the root number and seminal roottip elongation through promotion of increased root meristem activity (Sun et al., 2014; Manoli et al., 2016). However, in the presence of high concentrations of $\mathrm{NO}_{3}^{-}-\mathrm{N}$ nutrient solution will continue to stimulate the increase of cytokinin content, antagonize IAA, significantly reduce the IAA content (Caba et al., 2000; Walch-Liu et al., 2006) and promote the production of ethylene and ABA (Signora et al., 2001) in roots, thereby inhibiting the growth of roots (Tian et al., 2008, 2009). This may be the main reason for the inhibited root growth of pear seedlings under high $\mathrm{N}$-treatment conditions in this experiment. Furthermore, other studies showed highly significant negative correlations between the leaf nitrate content and total root growth (Marriott and Dale, 1977), suggesting

\section{REFERENCES}

Alvarez, J. M., Vidal, E. A., and Gutierrez, R. A. (2012). Integration of local and systemic signaling pathways for plant $\mathrm{N}$ responses. Curr. Opin. Plant Biol. 15, 185-191. doi: 10.1016/j.pbi.2012.03.009

Baozhang, B., Jinzhi, J., Liping, H., and Song, B. (1994). Improvement of TTC method determining root activity in corn [J]. Maize Sci. 4, 44-47.

Caba, J. M., Centeno, M. L., Fernandez, B., Gresshoff, P. M., and Ligero, F. (2000). Inoculation and nitrate alter phytohormone levels in soybean roots: differences between a supernodulating mutant and the wild type. Planta 211, 98-104. doi: $10.1007 / \mathrm{s} 004250000265$

Canales, J., Moyano, T. C., Villarroel, E., and Gutierrez, R. A. (2014). Systems analysis of transcriptome data provides new hypotheses about Arabidopsis root response to nitrate treatments. Front. Plant Sci. 5:22. doi: 10.3389/fpls.2014. 00022

Crawford, N. M., and Glass, A. D. M. (1998). Molecular and physiological aspects of nitrate uptake in plants. Trends Plant Sci. 3, 389-395. doi: 10.1016/S13601385(98)01311-9

Daughtry, C., Walthall, C., Kim, M., De Colstoun, E. B., and McMurtrey, J. (2000). Estimating corn leaf chlorophyll concentration from leaf and canopy reflectance. Remote Sens. Environ. 74, 229-239. doi: 10.1016/S0034-4257(00) 00113-9

Euring, D., Bai, H., Janz, D., and Polle, A. (2014). Nitrogen-driven stem elongation in poplar is linked with wood modification and gene clusters for stress, photosynthesis and cell wall formation. BMC Plant Biol. 14:391. doi: 10.1186/ S12870-014-0391-3

Feil, B., and Banziger, M. (1993). Nitrogen and cultivar effects on the mineral element concentration in the grain of spring wheat. Eur. J. Agron. 2, 205-212. doi: 10.1016/S1161-0301(14)80130-5

Fernández-Escobar, R., Benlloch, M., Herrera, E., and García-Novelo, J. M. (2004). Effect of traditional and slow-release $\mathrm{N}$ fertilizers on growth of olive nursery plants and $\mathrm{N}$ losses by leaching. Sci. Hortic. 101, 39-49. doi: 10.1016/j.scienta. 2003.09.008

Foehse, D., and Jungk, A. (1983). Influence of phosphate and nitrate supply on root hair formation of rape, spinach and tomato plants. Plant Soil 74, 359-368. doi: 10.1007/BF02181353 that nitrate in the leaf may act as a signal, reflecting internal $\mathrm{N}$ status and mediating root growth. Whether these mechanisms mentioned above are applicable to the pear seedlings under conditions of $\mathrm{N}$ deficiency and $\mathrm{N}$ excess needs to be further investigated.

\section{AUTHOR CONTRIBUTIONS}

GC designed the research, performed the experiments, and analyzed the results. LW drafted the manuscript. YT, PC, and QC participated in carrying out the experiments. KQ, SZ, and ST participated in revising the final manuscript. JW managed the experiments. All authors have read and approved the final manuscript.

\section{FUNDING}

This work was supported by the National Key Technology R\&D Program of the Ministry of Science and Technology of China (2014BAD16B03-4), the National Key R\&D Program of China (2018YFD0201400), and the Fundamental Research Funds for the Central Universities (KYTZ201602 and Y0201801062) and China Postdoctoral Science Foundation (2017M621760).

Forde, B., and Lorenzo, H. (2001). The nutritional control of root development. Plant Soil 232, 51-68. doi: 10.1023/A:1010329902165

Giles, J. (2005). Nitrogen study fertilizes fears of pollution. Nature 433, 791-791. doi: $10.1038 / 433791 \mathrm{a}$

Gruber, B. D., Giehl, R. F., Friedel, S., and von Wiren, N. (2013). Plasticity of the Arabidopsis root system under nutrient deficiencies. Plant Physiol. 163, 161-179. doi: 10.1104/pp.113.218453

Haluskova, L., Valentovicova, K., Huttova, J., Mistrik, I., and Tamas, L. (2009). Effect of abiotic stresses on glutathione peroxidase and glutathione S-transferase activity in barley root tips. Plant Physiol. Biochem. 47, 1069-1074. doi: 10.1016/j.plaphy.2009.08.003

Hansch, R., and Mendel, R. R. (2009). Physiological functions of mineral micronutrients $(\mathrm{Cu}, \mathrm{Zn}, \mathrm{Mn}, \mathrm{Fe}, \mathrm{Ni}, \mathrm{Mo}, \mathrm{B}, \mathrm{Cl})$. Curr. Opin. Plant Biol. 12, 259-266. doi: 10.1016/j.pbi.2009.05.006

Hirel, B., Bertin, P., Quillere, I., Bourdoncle, W., Attagnant, C., Dellay, C., et al. (2001). Towards a better understanding of the genetic and physiological basis for nitrogen use efficiency in maize. Plant Physiol. 125, 1258-1270. doi: 10.1104/ pp.125.3.1258

Hirel, B., Tétu, T., Lea, P. J., and Dubois, F. (2011). Improving nitrogen use efficiency in crops for sustainable agriculture. Sustainability 3, 1452-1485. doi: 10.3390/su3091452

Hirsch, R. E., and Sussman, M. R. (1999). Improving nutrient capture from soil by the genetic manipulation of crop plants. Trends Biotechnol. 17, 356-361. doi: 10.1016/S0167-7799(99)01332-3

Hoagland, D. R., and Arnon, D. I. (1950). The water-culture method for growing plants without soil. Circ. Calif. Agric. Exp. Stat. 347, 3-32.

Jaynes, D. B., Colvin, T. S., Karlen, D. L., Cambardella, C. A., and Meek, D. W. (2001). Nitrate loss in subsurface drainage as affected by nitrogen fertilizer rate. J. Environ. Qual. 30, 1305-1314. doi: 10.2134/jeq2001. 3041305x

Linkohr, B. I., Williamson, L. C., Fitter, A. H., and Leyser, H. M. O. (2002). Nitrate and phosphate availability and distribution have different effects on root system architecture of Arabidopsis. Plant J. 29, 751-760. doi: 10.1046/j.1365-313X. 2002.01251.x

Little, D. Y., Rao, H. Y., Oliva, S., Daniel-Vedele, F., Krapp, A., and Malamy, J. E. (2005). The putative high-affinity nitrate transporter NRT2.1 represses lateral 
root initiation in response to nutritional cues. Proc. Natl. Acad. Sci. U.S.A. 102, 13693-13698. doi: 10.1073/pnas.0504219102

Luo, J., Li, H., Liu, T., Polle, A., Peng, C., and Luo, Z. B. (2013). Nitrogen metabolism of two contrasting poplar species during acclimation to limiting nitrogen availability. J. Exp. Bot. 64, 4207-4224. doi: 10.1093/jxb/ert234

Lynch, J. (1995). Root architecture and plant productivity. Plant Physiol. 109, 7-13. doi: $10.1104 /$ pp.109.1.7

Maathuis, F. J. M. (2009). Physiological functions of mineral macronutrients. Curr. Opin. Plant Biol. 12, 250-258. doi: 10.1016/j.pbi.2009.04.003

Manoli, A., Trevisan, S., Voigt, B., Yokawa, K., Baluska, F., and Quaggiotti, S. (2016). Nitric oxide-mediated maize root apex responses to nitrate are regulated by auxin and strigolactones. Front. Plant Sci. 6:1269. doi: 10.3389/Fpls.2015. 01269

Marriott, C., and Dale, J. E. (1977). Effects of time of application of nitrate and leaf shading on root growth of plants of Hordeum vulgare L. grown in sand and in solution culture. Zeitschrift Für Pflanzenphysiologie 81, 377-385. doi: 10.1016/S0044-328X(77)80173-6

Masclaux-Daubresse, C., Daniel-Vedele, F., Dechorgnat, J., Chardon, F., Gaufichon, L., and Suzuki, A. (2010). Nitrogen uptake, assimilation and remobilization in plants: challenges for sustainable and productive agriculture. Ann. Bot Lond. 105, 1141-1157. doi: 10.1093/aob/mcq028

Norton, G. J., Dasgupta, T., Islam, M. R., Islam, S., Deacon, C. M., Zhao, F. J., et al. (2010). Arsenic influence on genetic variation in grain trace-element nutrient content in bengal delta grown rice. Environ. Sci. Technol. 44, 8284-8288. doi: $10.1021 /$ es $101487 \mathrm{x}$

Osmont, K. S., Sibout, R., and Hardtke, C. S. (2007). Hidden branches: developments in root system architecture. Annu. Rev. Plant Biol. 58, 93-113. doi: 10.1146/annurev.arplant.58.032806.104006

Sanchez-Rodriguez, E., Rubio-Wilhelmi, M., Cervilla, L. M., Blasco, B., Rios, J. J., Rosales, M. A., et al. (2010). Genotypic differences in some physiological parameters symptomatic for oxidative stress under moderate drought in tomato plants. Plant Sci. 178, 30-40. doi: 10.1016/j.plantsci.2009.10.001

Signora, L., De Smet, I., Foyer, C. H., and Zhang, H. (2001). ABA plays a central role in mediating the regulatory effects of nitrate on root branching in Arabidopsis. Plant J. 28, 655-662. doi: 10.1046/j.1365-313x.2001.01185.x

Sinha, S. K., Rani, M., Bansal, N., Gayatri Venkatesh, K., and Mandal, P. K. (2015). Nitrate starvation induced changes in root system architecture, carbon:nitrogen metabolism, and miRNA expression in nitrogen-responsive wheat genotypes. Appl. Biochem. Biotechnol. 177, 1299-1312. doi: 10.1007/s12010-0151815-8
Sofo, A., Scopa, A., Manfra, M., De Nisco, M., Tenore, G. C., and Nuzzo, V. (2013). Different water and light regimes affect ionome composition in grapevine (Vitis vinifera L.). Vitis 52, 13-20.

Sun, H. W., Tao, J. Y., Liu, S. J., Huang, S. J., Chen, S., Xie, X. N., et al. (2014). Strigolactones are involved in phosphate- and nitrate-deficiency-induced root development and auxin transport in rice. J. Exp. Bot. 65, 6735-6746. doi: 10. 1093/jxb/eru029

Thornton, I. (2002). Geochemistry and the mineral nutrition of agricultural livestock and wildlife. Appl. Geochem. 17, 1017-1028. doi: 10.1016/S08832927(02)00079-3

Tian, Q. Y., Chen, F. J., Liu, J. X., Zhang, F. S., and Mi, G. H. (2008). Inhibition of maize root growth by high nitrate supply is correlated with reduced IAA levels in roots. J. Plant Physiol. 165, 942-951. doi: 10.1016/j.jplph.2007.02.011

Tian, Q. Y., Sun, P., and Zhang, W. H. (2009). Ethylene is involved in nitratedependent root growth and branching in Arabidopsis thaliana. New Phytol. 184, 918-931. doi: 10.1111/j.1469-8137.2009.03004.x

Walch-Liu, P., Ivanov, I. I., Filleur, S., Gan, Y., Remans, T., and Forde, B. G. (2006). Nitrogen regulation of root branching. Ann. Bot. 97, 875-881. doi: $10.1093 / \mathrm{aob} / \mathrm{mcj} 601$

Wang, C., Chen, H. F., Hao, Q. N., Sha, A. H., Shan, Z. H., Chen, L. M., et al. (2012). Transcript profile of the response of two soybean genotypes to potassium deficiency. PLoS One 7:e39856. doi: 10.1371/journal.pone.0039856

Wu, J., Wang, Z. W., Shi, Z. B., Zhang, S., Ming, R., Zhu, S. L., et al. (2013). The genome of the pear (Pyrus bretschneideri Rehd.). Genome Res. 23, 396-408. doi: $10.1101 /$ gr.144311.112

Zhang, H. M., Jennings, A., Barlow, P. W., and Forde, B. G. (1999). Dual pathways for regulation of root branching by nitrate. Plant Biol. 96, 6529-6534. doi: $10.1073 /$ pnas.96.11.6529

Conflict of Interest Statement: The authors declare that the research was conducted in the absence of any commercial or financial relationships that could be construed as a potential conflict of interest.

Copyright (C) 2018 Chen, Wang, Fabrice, Tian, Qi, Chen, Cao, Wang, Zhang, Wu and Tao. This is an open-access article distributed under the terms of the Creative Commons Attribution License (CC BY). The use, distribution or reproduction in other forums is permitted, provided the original author(s) and the copyright owner(s) are credited and that the original publication in this journal is cited, in accordance with accepted academic practice. No use, distribution or reproduction is permitted which does not comply with these terms. 